\title{
Perancangan dan Penerapan Konten e-Learning melalui Learning Management System dalam Meningkatkan Motivasi Belajar Studi Kasus pada Mata Kuliah Pemrograman Basis Data
}

\author{
Elis Hernawati ${ }^{1)}$, Pramuko Aji ${ }^{2)}$ \\ ${ }^{1,2)}$ Program Studi D3 Manajemen Informatika, Fakultas Ilmu Terapan, Universitas Telkom \\ Jl. Telekomunikasi no 1 Dayeuh Kolot, Bandung \\ ${ }^{1)}$ elishernawati@tass.telkomuniversity.ac.id \\ ${ }^{2)}$ pramukoaji@tass.telkomuniversity.ac.id
}

\begin{abstract}
Abstrak - Mata Kuliah Pemrograman Basis Data merupakan salah satu mata kuliah inti dan memiliki kompetensi utama pada program studi D3 Manajemen Informatika di Fakultas Ilmu Terapan Unversitas Telkom. masih banyak mahasiswa yang merasa kesulitan mengikuti mata kuliah ini karena metode pembelajarannya masih dilakukan secara konvensional dengan pengajaran berpusat pada dosen. Dosen memberikan materi berupa slide di dalam kelas dan mahasiswa mendengarkan penjelasan dosen. Kegiatan belajar mengajar dilakukan secara terus menerus di dalam kelas. Hal ini membuat mahasiswa bosan dan menurunkan minat dan motivasi belajar mereka. Untuk mengatasi masalah ini penulis akan membuat suatu rancangan konten e-learning mata kuliah pemrograman basis data dan menerapkannya melalui Learning Management System (LMS) terintegrasi yang bernama iDea milik Universitas Telkom. Metode yang digunakan untuk membangun konten e-learning ini adalah metode prototype dan software aplikasi yang digunakan untuk pembuatan konten interaktif adalah Microsoft Power Point yang didalamnya terkandung teks, video, animasi flash dan narasi serta software aplikasi Wondershare QuizCreator untuk pembuatan soal interaktif. Untuk mengukur konten e-learning yang dihasilkan dilakukan pengujian dengan menggunakan kuesioner dan beberapa contoh soal dalam bentuk aplikasi media interaktif. Hasil pengujian akan memperlihatkan seberapa besar minat dan pemahaman mahasiswa terhadap konten e-learning yang telah dirancang.

Kata Kunci-Perancangan Konten, e-Learning, Media Interaktif

Abstract - Database Programming is one of the core courses and has core competencies in the study program of D3 Information Management at the School of Applied Science of Telkom University. There are many students who find it hard to follow this course because its learning methodology is still done conventionally with teacher-centered learning. The lecturers provide the materials in the form of slides and explain it in the classroom and the students listen to the lecturers' explanation. The learning activities are always carried out in the classroom. This makes the students bored and decreases their learning interest and motivation. To overcome this problem, the writer is going to create a design of e-learning contents for Database Programming course and implement it through an integrated Learning Management System (LMS) named IDEA that is owned by Telkom University. The method used to create this e-learning contents is the prototype method, the application used to create the interactive contents (that contain text, video, flash animation, and narration) is Microsoft PowerPoint, and the application used to create the interactive quiz is Wondershare Quiz Creator. An examination is done to measure the e-learning content created, by using questionnaires and some samples of questions in the form of interactive media application. The test results will show how much the interest and understanding of students to the e-learning content that has been created.
\end{abstract}

Keywords - Contents Design, e-Learning, Interactive Media

Article Histroy:

Received 13 February 2016; Received in revised form 9 April 2016; Accepted 14 April 2016; Available online 30 April 2016

\section{PENDAHULUAN}

Mata kuliah Pemrograman Basis Data merupakan mata kuliah inti program studi D3 Manajemen Informatika di Fakultas Ilmu Terapan Universitas Telkom. Mata kuliah ini merupakan salah satu mata kuliah paket dari kompetensi yang harus dimiliki mahasiswa program studi ini. Salah satu kompetensi yang harus dicapai oleh mahasiswa adalah mampu merancang bangun database dan terampil dalam pemrogramannya. Mata kuliah ini memiliki standar kompetensi yaitu membekali mahasiswa dengan keterampilan pemrograman basis data tingkat menengah.

Metode pengajaran untuk mata kuliah pemrograman database saat ini masih menggunakan cara konvensional. Dosen menyampaikan materi dengan menggunakan slide presentasi (Power Point) yang hanya memuat teks dan gambar yang bersifat statis. Mahasiswa menyimak materi kemudian dosen dengan dibantu asisten praktikum memberikan 
soal-soal latihan praktikum. Materi berupa slide diberikan kepada mahasiswa sebelum perkuliahan dimulai yang disebar melalui email atau aplikasi jejaring sosial. Materi slide presentasi yang bersifat statis dan metode pembelajaran yang masih konvensional menjadi salah satu kendala bagi mahasiswa dalam memahami mata kuliah pemrograman basis data saat ini. Mahasiswa sering lupa dengan langkah pengerjaan yang diajarkan dosen dalam melakukan pemrograman. Hal ini mengakibatkan mahasiswa merasa frustasi, bosan dan tidak bersemangat dalam mengikuti mata kuliah pemrograman basis data. Dilihat dari histori hasil evaluasi proses pembelajaran sebelumnya pada tahun akademik 2014/2015 masih terdapat mahasiswa yang tidak lulus mengikuti mata kuliah ini yaitu total $25 \%$ mahasiswa yang mendapatkan nilai D,E dan T. Sedangkan target kelulusan pada mata kuliah ini adalah 90\%. Berikut contoh salah satu hasil sebaran nilai mata kuliah pemrograman basis data pada salah satu kelas peminatan basis data.

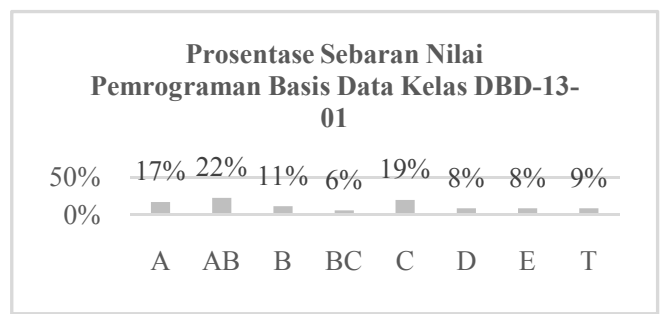

Gambar1. Prosentase Sebaran Nilai Pemrograman Basis Data

Ketidaklulusan mahasiswa ini akibat dari kurang pahamnya mahasiswa terhadap materi yang disampaikan oleh dosen, sehingga minat belajar mahasiswa terhadap mata kuliah ini berkurang.

LMS (Learning Management System) adalah sebuah perangkat lunak untuk membuat materi pembelajaran berbasis web yang mengelola kegiatan pembelajaran beserta hasilnya dan memfasilitasi interaksi antar dosen dan pembelajar, antar dosen dan dosen, dan antar pembelajar dan pembelajar (Permana, 2013).

Universitas Telkom memiliki sebuah Learning Management System yaitu Aplikasi elearning bernama iDea (Integrated Distance Education Application), yang saat ini dapat diakses melalui portal sistem informasi Universitas Telkom bernama iGracias (Tel-U Integrated Information System). Namun aplikasi e-learning ini belum digunakan secara optimal pada Proses Belajar Mengajar (PBM) khususnya di program studi D3 Manajemen Informatika. Hal ini karena belum tersedianya konten $e$ learning yang siap diterapkan pada portal iDea ini. Salah satunya adalah mata kuliah pemrograman basis data. Sedangkan mahasiswa membutuhkan ketersediaan materi pembelajaran yang dapat menuntun mereka untuk belajar lebih mandiri tidak harus selalu bergantung pada tatap muka di kelas. Selain itu mahasiswa membutuhkan tuntunan langkah demi langkah yang lebih menggambarkan lingkungan dan proses kerja yang realistik, serta membutuhkan media pembelajaran yang lebih 'hidup' sehingga mereka dapat lebih mudah menangkap materi yang diajarkan.

Dengan adanya permasalahan ini perlu dibangun konten e-learning untuk mata kuliah pemrograman basis data yang diintegrasikan pada aplikasi e-learning iDea Universitas Telkom. Konten e-learning yang dibangun menggunakan media pembelajaran yang bersifat interaktif agar menarik minat dan motivasi belajar mahasiswa. Salah satu media yang tepat untuk pembangunan konten mata kuliah ini adalah dalam bentuk aplikasi multimedia.

E-learning adalah pembelajaran yang disusun dengan tujuan menggunakan sistem elektronik atau komputer sehingga mampu mendukung proses pembelajaran (Allen, 2013).

E-learning merupakan proses pembelajaran jarak jauh dengan menggabungkan prinsipprinsip dalam proses pembelajaran dengan teknologi (Chandrawati, 2010). Menurut wiliam dengan metode e-learning (Online course content) memberikan kemudahan dan kelancaran proses belajar-mengajar baik bagi mahasiswa maupun dosen (Williams \& Stacey C S, 2007). Dengan metode e-learning, dosen dapat meningkatkan materi perkuliahan berbasis $e$ learning yang disampaikan melalui media elektronik komputer mempunyai teks, grafik, animasi, simulasi, audio dan video.

Pembelajaran dengan system e-learning, dapat membantu mahasiswa untuk lebih memahami materi mata kuliah karena mahasiswa dapat belajar secara mandiri kapan saja diluar perkuliahan. Selain itu dengan diimplementasikannya e-learning dosen tidak perlu memberikan materi secara berulang-ulang karena materi sudah disajikan melalui program multimedia.

Penelitian tentang perancangan dan penerapan konten mata kuliah berbasis $e$ learning telah banyak dilakukan diantaranya: penelitian yang ditulis dalam jurnal berjudul "Implementasi Konten E-Learning Mata Kuliah Fisika" (Budiawan \& Maesaroh, 2015), yaitu mengimplementasikan konten mata kuliah Fisika dengan menggunakan metode Blended Learning, metode ini menggabungkan metode konvensional dengan metode e-learning. Dalam penelitiaannya menghasilkan konten dan mengukur konten e-learning dengan menggunakan beberapa aspek pengukuran dari yang dilihat dari perspektif mahasiswa. Contoh penelitian berikutnya yang ditulis dalam jurnal 
berjudul "Rancang Bangun Media Perangkat Bantu Pembelajaran Berbasis E-Learning Untuk Mata Kuliah Pemrograman" (Faesal \& Dasriani, 2015), penelitiannya difokuskan pada pengembangan media pembelajaran berbasis moodle salah satu LMS yang bersifat open source yang dapat meningkatkan kemampuan dan penguasaan logika dan algoritma mahasiswa. Contoh penelitian berikutnya yang ditulis dalam jurnal berjudul: "Pengembangan Metode Pembelajaran Online Berbasis ELearning, Studi Kasus Mata Kuliah Bahasa Pemrograman" (Budi \& Nurjayanti, 2012), penelitiannya mengembangkan metode pembelajaran online berbasis e-learning untuk mata kuliah pemrograman pada progam Diploma IPB untuk meningkatkan motivasi belajar mahasiswa. Dari hasil penelitiannya disimpulkan dengan metode pembelajaran e-learning telah dapat membangun pola fikir komunikasi yang komprehensif dan interaktif kepada mahasiswa, dosen dan segenap sivitas akademika dan dapat dijadikan metode pembelajaran alternatif karena dirasakan cukup efektif dan efisien baik dari segi pelaksanaan maupun evaluasi pembelajarannya. Contoh penelitian berikutnya yang ditulis dalam prosiding berjudul : "Perancangan E-Learning untuk meningkatkan motivasi Guru dan Siswa" (Kosasi, 2015). Penelitian yang dihasilkan adalah perancangan $e$ learning untuk SMK Imanuael Pontianak guna menunjang proses belajar mengajar siswanya. Contoh Penelitiannya yang ditulis dalam jurnal berjudul: Penerapan e-learning sebagai suatu metode pembelajaran berbasis teknologi informasi, Studi Kasus: Mata Kuliah Pemrograman Berbasis Visual di STMIK PROVINSI (Hidayat \& Shinta, 2012). Dalam penelitiannya mengembangkan pembelajaran untuk mata kuliah pemrograman berbasis visual menggunakan moodle secara online di STMIK PROVISI Semarang.

Dengan dibangunnya konten mata kuliah pemrograman basis data berbasis multimedia yang diintegrasikan pada aplikasi e-learning iDea diharapkan mahasiswa program studi D3 Manajemen Informatika dapat belajar mandiri, memahami materi dan meningkatkan minat dan motivasi belajar khususnya terhadap mata kuliah pemrograman basis data.

\section{METODE PENELITIAN}

Penelitian dilakukan pada program studi D3 Manajemen Informatika Fakultas Ilmu Terapan di Universitas Telkom. Adapun yang menjadi objek penelitiaannya adalah mata kuliah pemrograman basis data. Penelitian ini menghasilkan konten pembelajaran dari mata kuliah pemrograman basis data yang akan integrasikan pada Aplikasi e-learning yang bernama iDea milik Universitas Telkom. Metode yang digunakan untuk membangun konten pembelajaran adalah Prototype. Metode ini terdiri dari tiga tahapan yaitu:

Listen to Customer, Build/Revise MockUp, dan Customer Test Drives Mock-Up. Model

Prototype dilakukan secara berulang hingga aplikasi yang dihasilkan sesuai dengan kebutuhan dan kesepekatan penggunanya (Pressman, 2010).

\section{A. Listen to Customer}

Tahap Listen to Customer adalah tahap pertama dari model prototype. Pada tahap ini dilakukan komunikasi dan mendengarkan kebutuhan terkait pembuatan konten e-learning dari para dosen pengajar dan koordinator mata kuliah pemrograman basis data sebelumnya untuk merumuskan menentukan format, media dan materi konten e-learning yang akan dibangun.

\section{B. Build/Revise Mock-up}

Tahap kedua dilakukan pembangunan mockup konten e-learning yaitu membangun media konten e-learning mata kuliah pemrograman basis data. Proses pembangunan mock-up dilakukan berulang-ulang secara periodik hingga sesuai dengan keinginan user yaitu dosen pengajar mata kuliah pemrograman basis data. Pada penelitian ini pengulangan atau revisi mock-up konten e-learning mata kuliah pemrograman basis data ditetapkan sebanyak tiga kali hingga sesuai dengan kebutuhan yang disepakati oleh para dosen pengajar mata kuliah pemrograman basis data.

\section{Customer Test Drives Mock-up}

Hasil akhir dari konten e-learning mata kuliah pemrograman basis data kemudian dievaluasi oleh beberapa pihak yaitu : dosen pengajar mata kuliah pemrograman basis data, mahasiswa yang akan dan sudah pernah mengambil mata kuliah ini serta tim dosen reviewer dari unit pengembangan pembelajaran Universitas Telkom.

\section{HASIL DAN PEMBAHASAN}

Tahap awal dari pembuatan konten $e$ learning adalah dilakukan analisis terhadap konten materi mata kuliah pemrograman basis data. Pada tahap analisis dilakukan "Listen to Customer" dengan koordinator dan para dosen pengajar mata kuliah pemrograman basis data untuk mengidentifikasi kebutuhan pembuatan konten e-learning.

\section{A. Sistem Pembelajaran yang Berjalan}

Sistem pembelajaran mata kuliah pemrograman basis data pada program studi D3 Manajemen Informatika, di Fakultas Ilmu Terapan Universitas Telkom pada saat ini masih menggunakan sistem konvensional dimana 
pengajaran berpusat pada dosen. Matakuliah pemrograman basis data memiliki beban $3 \mathrm{SKS}$, terdiri dari 1 sks teori yang diselenggarakan di kelas dan 2 sks praktikum diselenggarakan di laboratorium. Materi dalam mata kuliah pemrograman basis data terbagi menjadi tiga (3) kelompok kajian, yaitu:

1. Store Procedure dan Store Function

2. Package

3. Trigger

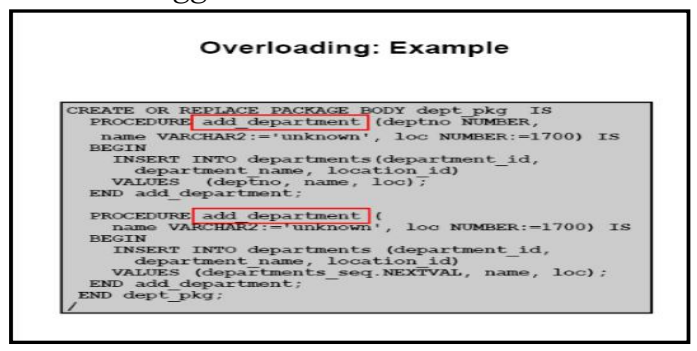

Gambar 2. Tampilan slide halaman contoh package yang digunakan saat ini

Materi yang diberikan berupa slide berisi teori, sintaks, dan contoh soal yang bersifat statis tanpa animasi, narasi, audio maupun video. Contoh salah satu slide materi yang saat ini digunakan dapat dilihat pada Gambar 2:

TABEL 1. PEMETAAN BOBOT NILAI

\begin{tabular}{|l|l|l|}
\hline Kompetensi & Kriteria Penilaian & Bobot \\
\hline Tidak Lulus & $\begin{array}{l}\text { Tidak memenuhi kriteria } \\
\text { kompetensi dasar }\end{array}$ & $0-5$ \\
\hline Dasar & $\begin{array}{l}\text { Mampu menyelesaikan }>=50 \% \\
\text { dari indikator kompetensi yang } \\
\text { diujikan }\end{array}$ & $6-10$ \\
\hline Menengah & $\begin{array}{l}\text { Mampu menyelesaikan }>=60 \% \\
\text { dari indikator kompetensi yang } \\
\text { diujikan }\end{array}$ & $11-15$ \\
\hline $\begin{array}{l}\text { Cukup } \\
\text { Mahir }\end{array}$ & $\begin{array}{l}\text { Mampu menyelesaikan }>=70 \% \\
\text { dari indikator kompetensi yang } \\
\text { diujikan }\end{array}$ & $16-20$ \\
\hline Mahir & $\begin{array}{l}\text { Mampu menyelesaikan }>=80 \% \\
\text { dari indikator kompetensi yang } \\
\text { diujikan }\end{array}$ & $21-25$ \\
\hline
\end{tabular}

Evaluasi hasil belajar menggunakan metoda assessment dibagi menjadi 3 bagian, yaitu :

1. Assessment kesatu mengevaluasi hasil belajar materi kajian kesatu

2. Assessment keduamengevaluasi hasil belajar materi kajian kedua

3. Assessment ketiga mengevaluasi hasil belajar materi kajian ketiga

Hasil evaluasi pembelajaran merupakan gabungan nilai assessment dan nilai tugas-tugas yang diberikan kepada mahasiswa, terdiri dari 5 kompetensi dengan yaitu : (1) Tidak Lulus, (2) Dasar,(3) Menengah, (4) Cukup Mahir,(5) Mahir. Penetapan bobot nilai untuk kompetensi diatas dirumuskan atas kesepakatan antara tim dosen pengampu mata kuliah pemrograman basis data dengan dosen koordinatornya. Adapun pemetaan bobot nilai untuk setiap kompetensi dapat dilihat pada Tabel 1.

\section{B. Hasil Build/Revise Mock-up}

Pada tahap kedua dilakukan pembangunan mock-up konten pembelajaran e-learning mata kuliah pemrograman basis data.

\section{1) Rancangan Media:}

Daftar rancangan media konten e-learning mata kuliah pemrograman basis data dapat dilihat pada Tabel 2 dan Tabel 3.

TABEL 2. DAFTAR KONTEN E-LEARNING DAN RANCANGAN MEDIA YANG DIGUNAKAN BAGIAN 1

\begin{tabular}{|c|c|c|}
\hline Kajian & $\begin{array}{c}\text { Pokok } \\
\text { Bahasan }\end{array}$ & $\begin{array}{c}\text { Media Yang } \\
\text { Digunakan }\end{array}$ \\
\hline \multirow{8}{*}{1} & $\begin{array}{l}\text { Blok PL/SQL } \\
\text { Non Modular vs } \\
\text { Modular }\end{array}$ & $\begin{array}{l}\text { Media yang digunakan } \\
\text { adalah slide Microsoft } \\
\text { Power Point kaya yang } \\
\text { di dalamnya terkandung } \\
\text { teks, animasi, dan narasi } \\
\text { (voice over) }\end{array}$ \\
\hline & $\begin{array}{l}\text { Pembuatan \& } \\
\text { Struktur Stored } \\
\text { Procedure } \\
\text { Tanpa } \\
\text { Parameter }\end{array}$ & $\begin{array}{l}\text { Media yang digunakan } \\
\text { adalah slide Microsoft } \\
\text { Power Point kaya yang } \\
\text { di dalamnya terkandung } \\
\text { teks, video, animasi } \\
\text { Flash, ilustrasi gambar, } \\
\text { dan narasi (voice over). }\end{array}$ \\
\hline & $\begin{array}{l}\text { Pembuatan \& } \\
\text { Struktur Stored } \\
\text { Procedure } \\
\text { Dengan } \\
\text { Parameter }\end{array}$ & $\begin{array}{l}\text { Media yang digunakan } \\
\text { adalah slide Microsoft } \\
\text { Power Point kaya yang } \\
\text { di dalamnya terkandung } \\
\text { teks, video, animasi } \\
\text { Flash, ilustrasi gambar, } \\
\text { dan narasi (voice over). }\end{array}$ \\
\hline & $\begin{array}{l}\text { Pembuatan \& } \\
\text { Struktur Stored } \\
\text { Function Tanpa } \\
\text { Parameter }\end{array}$ & $\begin{array}{l}\text { Media yang digunakan } \\
\text { adalah slide Microsoft } \\
\text { Power Point kaya yang } \\
\text { di dalamnya terkandung } \\
\text { teks, video, animasi } \\
\text { Flash, ilustrasi gambar, } \\
\text { dan narasi (voice over). }\end{array}$ \\
\hline & $\begin{array}{l}\text { Pembuatan \& } \\
\text { Struktur Stored } \\
\text { Function } \\
\text { Dengan } \\
\text { Parameter }\end{array}$ & $\begin{array}{l}\text { Media yang digunakan } \\
\text { adalah slide Microsoft } \\
\text { Power Point kaya yang } \\
\text { di dalamnya terkandung } \\
\text { teks, video, animasi } \\
\text { Flash, ilustrasi gambar, } \\
\text { dan narasi (voice over). }\end{array}$ \\
\hline & $\begin{array}{l}\text { Non Predefined } \\
\text { Exception }\end{array}$ & $\begin{array}{l}\text { Media yang digunakan } \\
\text { adalah slide Microsoft } \\
\text { Power Point kaya yang } \\
\text { di dalamnya terkandung } \\
\text { teks, video, animasi } \\
\text { Flash, ilustrasi gambar, } \\
\text { dan narasi (voice over). }\end{array}$ \\
\hline & $\begin{array}{l}\text { User Defined } \\
\text { Exception }\end{array}$ & $\begin{array}{l}\text { Media yang digunakan } \\
\text { adalah slide Microsoft } \\
\text { Power Point kaya yang } \\
\text { di dalamnya terkandung } \\
\text { teks, video, animasi } \\
\text { Flash, ilustrasi gambar, } \\
\text { dan narasi (voice over). }\end{array}$ \\
\hline & $\begin{array}{l}\text { ASSESSMENT } \\
\text { KAJIAN } 1\end{array}$ & $\begin{array}{l}\text { Media yang digunakan } \\
\text { LMS IDEA Universitas } \\
\text { Telkom }\end{array}$ \\
\hline
\end{tabular}


TABEL 3. DAFTAR KONTEN E-LEARNING DAN RANCANGAN MEDIA YANG DIGUNAKAN BAGIAN 2

\begin{tabular}{|c|c|c|}
\hline Kajian & $\begin{array}{c}\text { Pokok } \\
\text { Bahasan }\end{array}$ & $\begin{array}{l}\text { Media Yang } \\
\text { Digunakan }\end{array}$ \\
\hline \multirow[t]{3}{*}{2} & $\begin{array}{l}\text { Package } \\
\text { (Package } \\
\text { Spesification } \\
\text { and Body, } \\
\text { Public \&Private } \\
\text { Component, } \\
\text { Package } \\
\text { Variable) }\end{array}$ & $\begin{array}{l}\text { Media yang digunakan } \\
\text { adalah slide Microsoft } \\
\text { Power Point kaya yang } \\
\text { di dalamnya terkandung } \\
\text { teks, video, animasi, } \\
\text { ilustrasi gambar, dan } \\
\text { narasi (voice over). }\end{array}$ \\
\hline & $\begin{array}{l}\text { Overloading } \\
\text { Package, } \\
\text { Package } \\
\text { Initialization } \\
\text { Block \& } \\
\text { Persistent State }\end{array}$ & $\begin{array}{l}\text { Media yang digunakan } \\
\text { adalah slide Microsoft } \\
\text { Power Point kaya yang } \\
\text { di dalamnya terkandung } \\
\text { teks, video, animasi, } \\
\text { ilustrasi gambar, dan } \\
\text { narasi (voice over). }\end{array}$ \\
\hline & $\begin{array}{l}\text { ASSESSMENT } \\
\text { KAJIAN } 2\end{array}$ & $\begin{array}{l}\text { Media yang digunakan } \\
\text { LMS IDEA Universitas } \\
\text { Telkom }\end{array}$ \\
\hline \multirow{5}{*}{3} & $\begin{array}{l}\text { Statement \& } \\
\text { Row Trigger }\end{array}$ & $\begin{array}{l}\text { Media yang digunakan } \\
\text { adalah slide Microsoft } \\
\text { Power Point kaya yang } \\
\text { di dalamnya terkandung } \\
\text { teks, video, animasi } \\
\text { Flash, ilustrasi gambar, } \\
\text { dan narasi (voice over). }\end{array}$ \\
\hline & $\begin{array}{l}\text { Manajemen } \\
\text { Trigger }\end{array}$ & $\begin{array}{l}\text { Media yang digunakan } \\
\text { adalah slide Microsoft } \\
\text { Power Point kaya yang } \\
\text { di dalamnya terkandung } \\
\text { teks, video, animasi, } \\
\text { ilustrasi gambar, dan } \\
\text { narasi (voice over). }\end{array}$ \\
\hline & $\begin{array}{l}\text { Mutating Table } \\
\& \text { Instead of } \\
\text { Trigger }\end{array}$ & $\begin{array}{l}\text { Media yang digunakan } \\
\text { adalah slide Microsoft } \\
\text { Power Point kaya yang } \\
\text { di dalamnya terkandung } \\
\text { teks, video, ilustrasi } \\
\text { gambar, dan narasi } \\
\text { (voice over). }\end{array}$ \\
\hline & $\begin{array}{l}\text { Procedure, } \\
\text { Function, } \\
\text { Package, } \\
\text { Trigger }\end{array}$ & $\begin{array}{l}\text { Media yang digunakan } \\
\text { adalah slide Microsoft } \\
\text { Power Point kaya yang } \\
\text { di dalamnya terkandung } \\
\text { teks, video, ilustrasi } \\
\text { gambar, dan narasi } \\
\text { (voice over). }\end{array}$ \\
\hline & $\begin{array}{l}\text { ASSESSMENT } \\
\text { KAJIAN } 3\end{array}$ & $\begin{array}{l}\text { Media yang digunakan } \\
\text { LMS IDEA Universitas } \\
\text { Telkom }\end{array}$ \\
\hline
\end{tabular}

\section{2) Tampilan Konten Materi dan Tugas}

Konten materi e-learning dibangun menggunakan software aplikasi Microsoft Power Point yang diperkaya dengan animasi, audio dan video di embed ke dalam power point tersebut. Sedangkan tugas dibangun dengan menggunakan software multimedia interaktif yaitu Wondershare QuizCreator dan Macromedia Flash.

Konten materi berisi penjelasan teori, sintaks umum dan contoh latihan soal berupa video tutorial. Sedangkan konten tugas berisi kumpulan soal yang bisa dijawab secara interaktif oleh mahasiswa. Dan dibagian akhir akan dimunculkan informasi score.

Gambar 3-6 merupakan beberapa contoh tampilan layar (on-screen display) konten materi dan tugas e-learning mata kuliah pemrograman basis data:

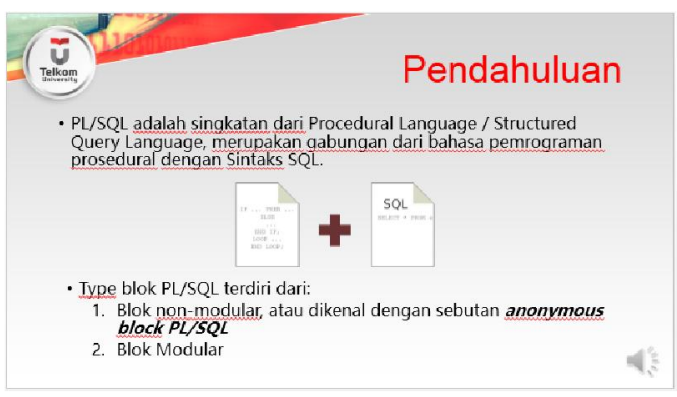

Gambar 3. Tampilan halaman kedua konten Blok PL/SQL

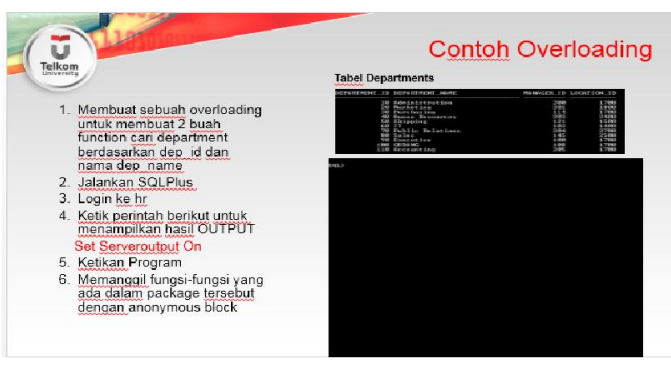

Gambar 4. Tampilan halaman kelima konten Package Lanjutan

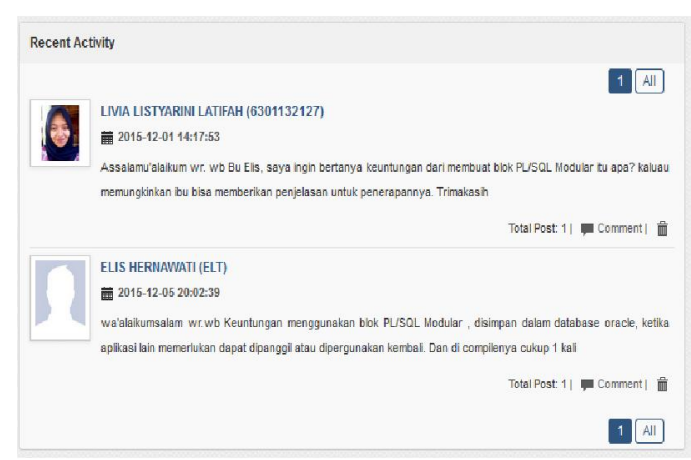

Gambar 5. Tampilan Media Interaktif Menu Score Tugas 2

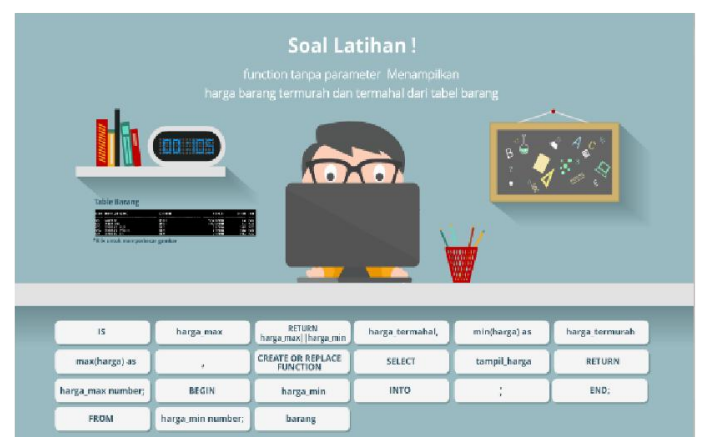

Gambar 6. Tampilan Media Interaktif Soal Latihan 


\section{3) Tampilan Konten Forum Diskusi dan} Assessment

Konten Forum Diskusi dan Soal Assessment dibuat menggunakan aplikasi iDea. Untuk Soal assessment dibuat menggunakan aplikasi iDea pada menu Quiz. Soal assessment dibuat hanya dalam bentuk pilihan ganda karena aplikasi iDea belum dapat mengadopsi jenis format selain pilihan ganda. Tampilan form diskusi dan soal assessment/quiz dapat dilihat pada Gambar 7-9.

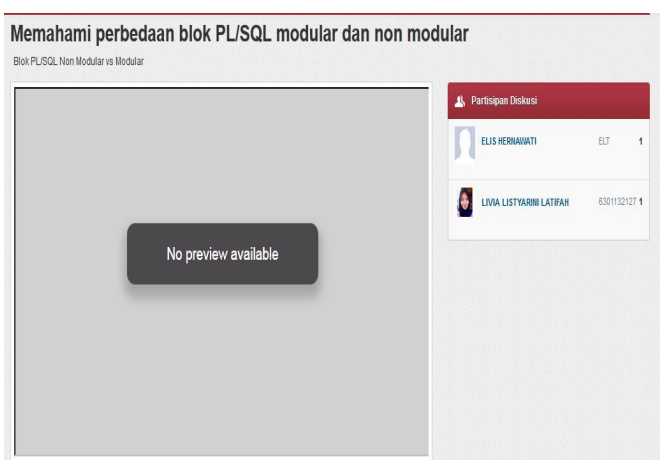

Gambar 7. Tampilan awal Menu Forum Diskusi

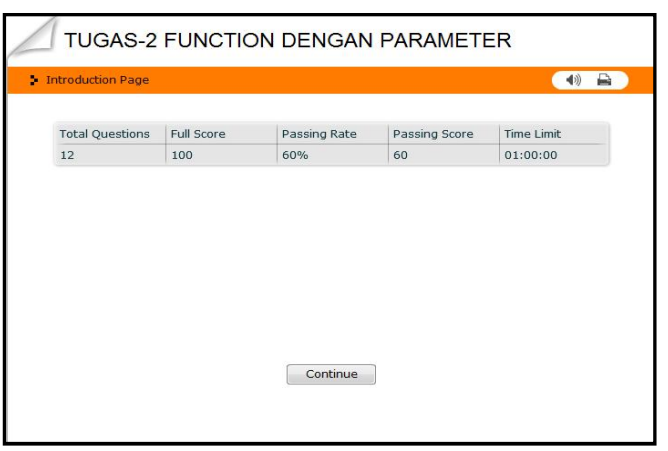

Gambar 8. Tampilan Menu detil forum diskusi

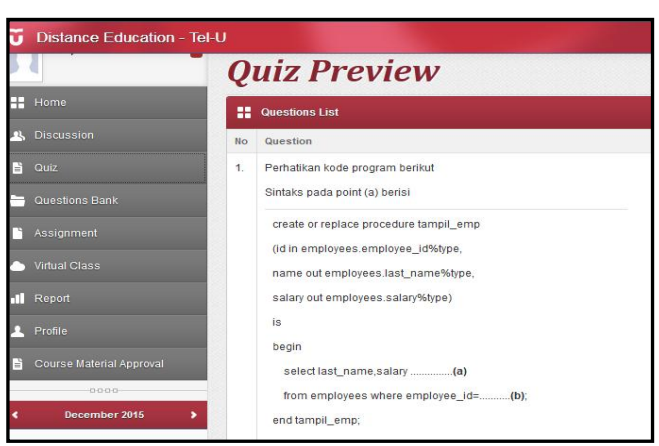

Gambar 9. Tampilan Menu soal Assessment Quiz Kajian 1

\section{4) Implementasi Konten e-learning padaPortal iDea}

iDea adalah aplikasi LMS milik Universitas Telkom. Portal ini belum digunakan pada kegiatan belajar mengajar di Program Studi D3 Manajemen Informatika karena masih dilakukan pengembangan untuk konten matakuliah berbasis e-learning. Konten materi, tugas dan soal assessment/quiz mata kuliah pemrograman basis data yang telah dibangun telah di upload pada portal ini untuk kemudian diujicobakan kepada mahasiswa.

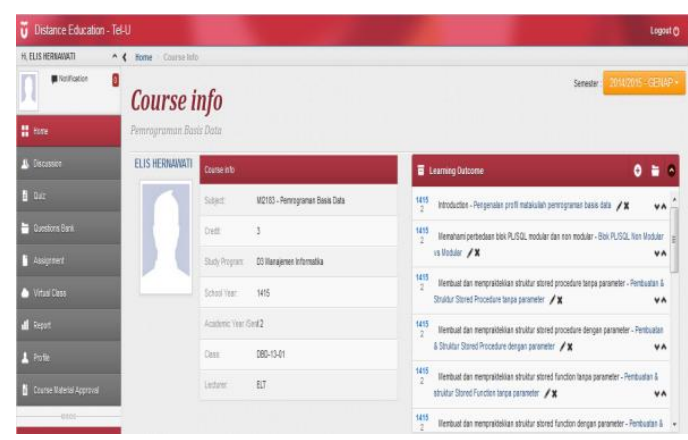

Gambar 10. Halaman Utama
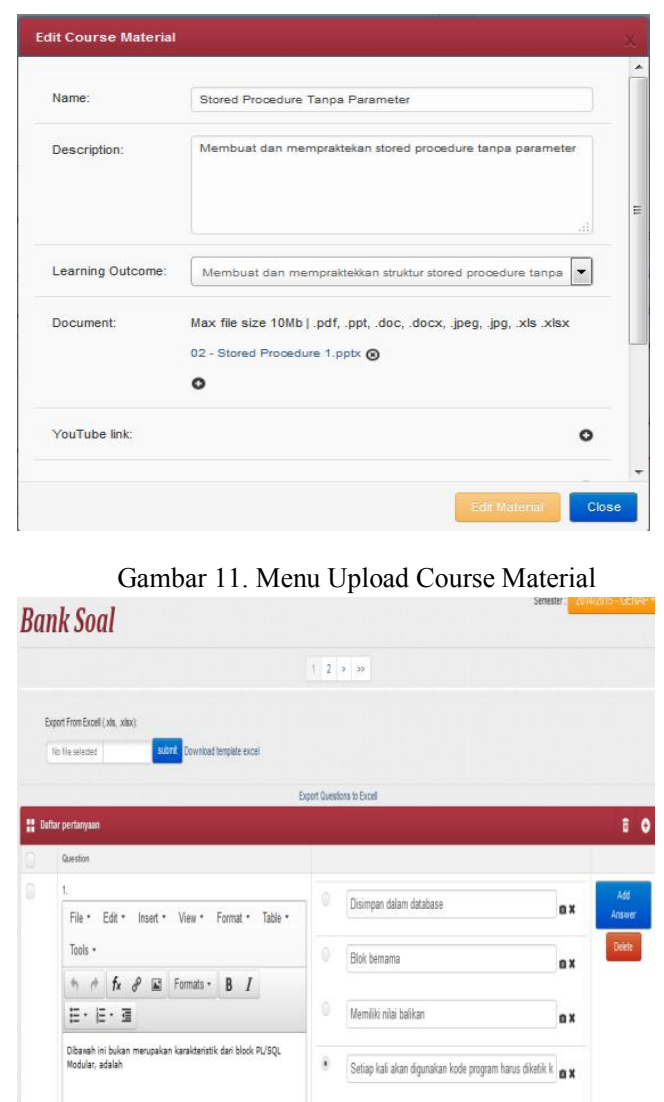

Gambar 13. Menu Upload Bank Soal

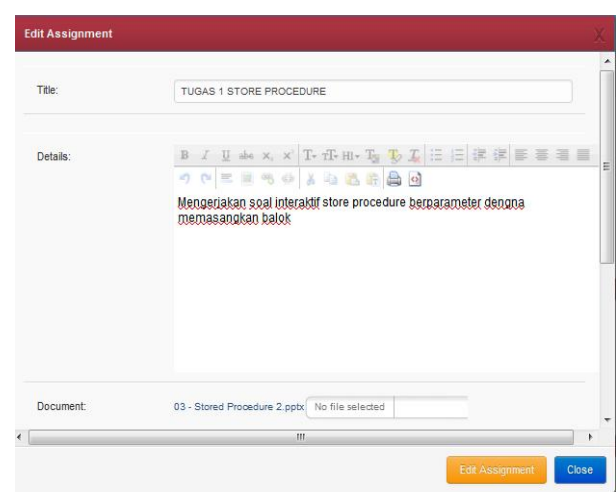

Gambar 12. Menu upload Tugas 
Gambar 10-12 merupakan beberapa tampilan halaman iDea dan beberapa konten dari mata kuliah pemrograman basis data yang telah diupload .

TABEL 4. DAFTAR KONTEN YANG DIUJIKAN KEPADA MAHASISWA

\begin{tabular}{|c|c|c|c|c|}
\hline No & $\begin{array}{c}\text { Pokok } \\
\text { Bahasan / } \\
\text { Sub } \\
\text { Bahasan }\end{array}$ & $\begin{array}{c}\text { Nama } \\
\text { Konten } \\
\text { yang } \\
\text { Diuji }\end{array}$ & $\begin{array}{c}\text { Jumah } \\
\text { Mahasiswa } \\
\text { yang } \\
\text { Berpartisi- } \\
\text { pasi }\end{array}$ & $\begin{array}{l}\text { Alat Bantu } \\
\text { Pengujian }\end{array}$ \\
\hline 0 & $\begin{array}{l}\text { Blok } \\
\text { PL/SQL } \\
\text { Non } \\
\text { Modular vs } \\
\text { Modular }\end{array}$ & Forum 1 & 30 & Kuesioner \\
\hline 1 & $\begin{array}{l}\text { Pembuatan } \\
\text { \& Struktur } \\
\text { Stored } \\
\text { Procedure } \\
\text { Tanpa } \\
\text { Parameter }\end{array}$ & $\begin{array}{l}02- \\
\text { Stored } \\
\text { Procedur } \\
\text { e 1.pptx }\end{array}$ & 30 & $\begin{array}{l}\text { Latihan } \\
\text { Interaktif 1, } \\
\text { Kuesioner }\end{array}$ \\
\hline 2 & $\begin{array}{l}\text { Pembuatan } \\
\& \text { Struktur } \\
\text { Stored } \\
\text { Procedure } \\
\text { Dengan } \\
\text { Parameter }\end{array}$ & $\begin{array}{l}03- \\
\text { Stored } \\
\text { Procedur } \\
\text { e 2.pptx }\end{array}$ & 30 & $\begin{array}{l}\text { Latihan } \\
\text { Interaktif 2, } \\
\text { Tugas 1, } \\
\text { Kuesioner }\end{array}$ \\
\hline 4 & $\begin{array}{l}\text { Pembuatan } \\
\text { \& Struktur } \\
\text { Stored } \\
\text { Function } \\
\text { Tanpa } \\
\text { Parameter }\end{array}$ & $\begin{array}{l}04- \\
\text { Stored } \\
\text { Function } \\
\text { 1.pptx }\end{array}$ & 30 & $\begin{array}{l}\text { Latihan } \\
\text { Interaktif 3, } \\
\text { Kuesioner }\end{array}$ \\
\hline 5 & $\begin{array}{l}\text { Pembuatan } \\
\text { \& Struktur } \\
\text { Stored } \\
\text { Function } \\
\text { Dengan } \\
\text { Parameter }\end{array}$ & $\begin{array}{l}05- \\
\text { Stored } \\
\text { Function } \\
\text { 2.pptx }\end{array}$ & 30 & $\begin{array}{l}\text { Latihan } \\
\text { Interaktif 3, } \\
\text { Tugas 2, } \\
\text { Kuesioner }\end{array}$ \\
\hline 6 & $\begin{array}{l}\text { Non } \\
\text { Predefined } \\
\text { Exception }\end{array}$ & $\begin{array}{l}\text { 06- } \\
\text { Exceptio } \\
\mathrm{n} \\
\text { Handling } \\
\text { 1.pptx }\end{array}$ & 30 & Kuesioner \\
\hline 7 & $\begin{array}{l}\text { User } \\
\text { Defined } \\
\text { Exception }\end{array}$ & $\begin{array}{l}07- \\
\text { Exceptio } \\
\mathrm{n} \\
\text { Handling } \\
\text { 2.pptx }\end{array}$ & 30 & $\begin{array}{l}\text { Latihan } \\
\text { Interaktif 1, } \\
\text { Tugas 3, } \\
\text { Kuesioner }\end{array}$ \\
\hline 8 & & Quiz idea & 30 & $\begin{array}{l}\text { Soal Quiz } \\
\text { Idea }\end{array}$ \\
\hline
\end{tabular}

C. Hasil Customer Test Drives Mock-up

Konten e-learning yang telah dibangun kemudian dilakukan pengujian konten pada mahasiswa Program Studi D3 Manajemen Informatika. Pengujian dilakukan terhadap mahasiswa yang sudah dan belum mengambil mata kuliah ini. Daftar Pengujian untuk konten $e$ learning dapat dilihat pada Tabel 4.

Kuesioner disebarkan kepada 30 orang mahasiswa. Kuesioner terbagi menjadi dua kelompok pertanyaan. Kelompok pertanyaan pertama terdiri dari 8 pertanyaan-pertanyaan yang berkaitan dengan persepsi pengguna atas kualitas konten. Kelompok pertanyaan kedua berisi 5 pertanyaan yang berkaitan dengan ketertarikan dan minat responden terhadap konten e-learning yang diujikan.

TABEL 5. FREKUENSI SIKAP RESPONDEN TERHADAP KONTEN E-LEARNING PEMROGRAMAN BASIS DATA

\begin{tabular}{|c|c|c|c|c|c|}
\hline Pernyataan & $\underbrace{e^{e}}_{\mathscr{a}}$ & $\underbrace{\frac{\partial}{e}}_{n}$ & 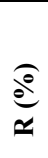 & $\underbrace{\frac{\partial}{2}}_{n}$ & $\underbrace{e^{2}}_{\substack{0 \\
\infty}}$ \\
\hline $\begin{array}{l}\text { Tampilan slide menarik dan } \\
\text { indah. }\end{array}$ & 20 & 80 & 0 & 0 & 0 \\
\hline $\begin{array}{l}\text { Teks pada slide dapat terlihat } \\
\text { jelas. }\end{array}$ & 33 & 57 & 7 & 3 & 0 \\
\hline $\begin{array}{l}\text { Penjelasan konsep-konsep } \\
\text { dapat mudah dimengerti. }\end{array}$ & 13 & 57 & 30 & 0 & 0 \\
\hline $\begin{array}{l}\text { Audio dapat didengar dengan } \\
\text { jelas. }\end{array}$ & 17 & 63 & 10 & 10 & 0 \\
\hline $\begin{array}{l}\text { Video contoh pembuatan } \\
\text { program terlihat jelas. }\end{array}$ & 13 & 57 & 27 & 3 & 0 \\
\hline $\begin{array}{l}\text { Video contoh pembuatan } \\
\text { program dapat diikuti dan } \\
\text { dimengerti. }\end{array}$ & 13 & 37 & 50 & 0 & 0 \\
\hline $\begin{array}{l}\text { Instruksi soal assessment dan } \\
\text { tugas dapat Anda pahami. }\end{array}$ & 7 & 43 & 50 & 0 & 0 \\
\hline $\begin{array}{l}\text { Soal-soal assessment dan } \\
\text { tugas dapat diselesaikan } \\
\text { sesuai dengan waktu yang } \\
\text { disediakan. }\end{array}$ & 7 & 53 & 33 & 7 & 0 \\
\hline $\begin{array}{l}\text { Belajar menggunakan materi } \\
\text { e-learning ini mendorong } \\
\text { Anda ingin mempelajari } \\
\text { pemrograman basis data lebih } \\
\text { jauh. }\end{array}$ & 17 & 73 & 10 & 0 & 0 \\
\hline $\begin{array}{l}\text { Belajar menggunakan materi } \\
\text { e-learning ini terasa } \\
\text { menyenangkan. }\end{array}$ & 23 & 60 & 17 & 0 & 0 \\
\hline $\begin{array}{l}\text { Adanya materi e-learning ini } \\
\text { menolong Anda belajar } \\
\text { secara mandiri. }\end{array}$ & 30 & 57 & 13 & 0 & 0 \\
\hline $\begin{array}{l}\text { Adanya materi e-learning ini } \\
\text { memberikan Anda } \\
\text { kemudahan dalam } \\
\text { mempelajari pemrograman } \\
\text { basis data. }\end{array}$ & 27 & 60 & 13 & 0 & 0 \\
\hline
\end{tabular}

Kuesioner menggunakan skala Likert lima item, terdiri dari sikap Sangat Setuju (SS), Setuju (S), Ragu-ragu (R), Tidak Setuju (TS), Sangat Tidak Setuju (STS).

Pertanyaan-pertanyaan kuesioner adalah sebagai berikut:

1. Tampilan slide menarik dan indah.

2. Teks pada slide dapat terlihat jelas. 
3. Penjelasan konsep-konsep dapat mudah dimengerti.

4. Audio dapat didengar dengan jelas.

5. Video contoh pembuatan program terlihat jelas.

6. Video contoh pembuatan program dapat diikuti dan dimengerti.

7. Instruksi soal assessment dan tugas dapat Anda pahami.

8. Soal-soal assessment dan tugas dapat diselesaikan sesuai dengan waktu yang disediakan.

9. Belajar menggunakan materi e-learning ini mendorong Anda ingin mempelajari pemrograman basis data lebih jauh.

10. Belajar menggunakan materi e-learning ini terasa menyenangkan.

11. Adanya materi e-learning ini menolong Anda belajar secara mandiri.

12. Adanya materi e-learning ini memberikan Anda kemudahan dalam mempelajari pemrograman basis data

13. Adanya materi e-learning ini meningkatkan minat Anda dalam mempelajari pemrograman basis data

Frekuensi sikap responden ditampilkan pada table 5. Analisa dilakukan dengan menggunakan statistika deskriptif sederhana. Hasilnya disajikan dalam tabel berik6:

TABEL 6. STATISTIKA DESKRIPTIF KUESIONER

\begin{tabular}{|c|c|c|c|}
\hline Pernyataan & $\frac{0}{\overbrace{0}^{\circ}}$ & 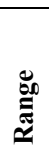 & 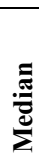 \\
\hline Tampilan slide menarik dan indah. & $\mathrm{S}$ & 1 & $\mathrm{~S}$ \\
\hline Teks pada slide dapat terlihat jelas. & $\mathrm{S}$ & 3 & $\mathrm{~S}$ \\
\hline $\begin{array}{l}\text { Penjelasan konsep-konsep dapat mudah } \\
\text { dimengerti. }\end{array}$ & $\mathrm{S}$ & 2 & $\mathrm{~S}$ \\
\hline Audio dapat didengar dengan jelas. & $\mathrm{S}$ & 3 & $\mathrm{~S}$ \\
\hline $\begin{array}{l}\text { Video contoh pembuatan program terlihat } \\
\text { jelas. }\end{array}$ & $\mathrm{S}$ & 3 & $\mathrm{~S}$ \\
\hline $\begin{array}{l}\text { Video contoh pembuatan program dapat } \\
\text { diikuti dan dimengerti. }\end{array}$ & $\mathrm{R}$ & 2 & $\mathrm{~S}$ \\
\hline $\begin{array}{l}\text { Instruksi soal assessment dan tugas dapat } \\
\text { Anda pahami. }\end{array}$ & $\mathrm{R}$ & 2 & $\mathrm{~S}$ \\
\hline $\begin{array}{l}\text { Soal-soal assessment dan tugas dapat } \\
\text { diselesaikan sesuai dengan waktu yang } \\
\text { disediakan. }\end{array}$ & $\mathrm{S}$ & 3 & $\mathrm{~S}$ \\
\hline $\begin{array}{l}\text { Belajar menggunakan materi e-learning ini } \\
\text { mendorong Anda ingin mempelajari } \\
\text { pemrograman basis data lebih jauh. }\end{array}$ & $\mathrm{S}$ & 2 & $\mathrm{~S}$ \\
\hline $\begin{array}{l}\text { Belajar menggunakan materi e-learning ini } \\
\text { terasa menyenangkan. }\end{array}$ & $\mathrm{S}$ & 2 & $\mathrm{~S}$ \\
\hline $\begin{array}{l}\text { Adanya materi e-learning ini menolong } \\
\text { Anda belajar secara mandiri. }\end{array}$ & $\mathrm{S}$ & 2 & $\mathrm{~S}$ \\
\hline $\begin{array}{l}\text { Adanya materi e-learning ini memberikan } \\
\text { Anda kemudahan dalam mempelajari } \\
\text { pemrograman basis data. }\end{array}$ & $\mathrm{S}$ & 2 & $\mathrm{~S}$ \\
\hline
\end{tabular}

Dari tabel di atas, dapat diketahui bahwa hampir semua pernyataan memperoleh respon positif (Setuju dan Sangat Setuju). Hal ini diketahui dari modus dan median yang terletak pada jawaban S (Setuju). Namun terdapat dua pernyataan yang modus responnya adalah Raguragu, yaitu pernyataan-pernyataan berikut:

1. Video contoh pembuatan program dapat diikuti dan dimengerti.

2. Instruksi soal assessment dan tugas dapat Anda pahami.

Nilai mahasiswa tidak diambil dari tugas dan assessment riil karena pada saat konten $e$ learning dibuat dan diuji, mata kuliah ini tidak sedang diadakan. Untuk mengetahui pemahaman mahasiswa, tugas dan assessment diujikan kepada para tester.

Untuk diketahui bahwa tugas yang diberikan untuk penilaian berbeda dengan tugas berbasis media interaktif Flash yang dibahas pada kuesioner sebelumnya. Media interaktif Flash dibuat untuk tujuan latihan mandiri tanpa ada penilaian. Rangkuman nilai responden disajikan dalam Tabel 7 berikut:

TABEL 7.DAFTAR NILAI TUGAS DAN ASSESSMENT

\begin{tabular}{|c|c|c|c|c|c|c|c|}
\hline 离 & $\mathbf{N}$ & $\sum_{\Sigma}^{\Xi}$ & 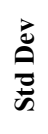 & 龍 & 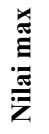 & 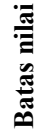 & 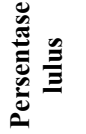 \\
\hline $\begin{array}{l}\text { Tugas } \\
1\end{array}$ & 21 & 82,62 & $\begin{array}{r}27, \\
96\end{array}$ & 25 & $\begin{array}{r}10 \\
0\end{array}$ & $\begin{array}{l}6 \\
0\end{array}$ & 76,19 \\
\hline $\begin{array}{l}\text { Tugas } \\
2\end{array}$ & 19 & 74,74 & $\begin{array}{r}29, \\
13\end{array}$ & 10 & $\begin{array}{r}10 \\
0\end{array}$ & $\begin{array}{l}6 \\
0\end{array}$ & 84,21 \\
\hline $\begin{array}{l}\text { Tugas } \\
3\end{array}$ & 18 & 80,83 & $\begin{array}{r}25, \\
45\end{array}$ & 35 & $\begin{array}{r}10 \\
0\end{array}$ & $\begin{array}{l}6 \\
0 \\
\end{array}$ & 77,78 \\
\hline $\begin{array}{l}\text { Assess- } \\
\text { ment } 1\end{array}$ & 17 & 85,29 & $\begin{array}{r}12, \\
31\end{array}$ & 50 & $\begin{array}{r}10 \\
0\end{array}$ & $\begin{array}{l}6 \\
0\end{array}$ & 94,12 \\
\hline
\end{tabular}

TABEL 8. PERBANDINGAN SASARAN E-LEARNING DENGAN REALISASINYA

\begin{tabular}{|c|c|c|c|c|}
\hline No & $\begin{array}{c}\text { Sasaran } \\
\text { Implementasi } e- \\
\text { Learning }\end{array}$ & $\begin{array}{c}\text { Nilai } \\
\text { Target } \\
\text { Sasaran }\end{array}$ & $\begin{array}{c}\text { Realisasi } \\
\text { Target }\end{array}$ & $\begin{array}{l}\text { Gap } \\
(\mathrm{OFI})\end{array}$ \\
\hline 1 & $\begin{array}{l}\text { Mengetahui } \\
\text { seberapa besar } \\
\text { minat mahasiswa } \\
\text { untuk mempelajari } \\
\text { materi mata kuliah } \\
\text { pemrograman } \\
\text { basis data. }\end{array}$ & $60 \%$ & $87 \%$ & $\begin{array}{l}\text { Sudah } \\
\text { tercapai }\end{array}$ \\
\hline 2 & $\begin{array}{l}\text { Mengetahui } \\
\text { seberapa besar } \\
\text { pemahaman } \\
\text { mahasiswa } \\
\text { terhadap materi } \\
\text { mata kuliah } \\
\text { pemrograman } \\
\text { basis data. }\end{array}$ & $60 \%$ & $83 \%$ & $\begin{array}{l}\text { Sudah } \\
\text { tercapai }\end{array}$ \\
\hline
\end{tabular}


Dari respons yang terkumpul dapat diketahui bahwa nilai-nilai tugas dan assessment yang dicapai sangat memuaskan. Pencapaian nilai yang relatif tinggi pada Table 8 sejalan dengan respon mahasiswa yang cenderung setuju atas pernyataan 2, 3, dan 4 pada kuesioner.

Hasil Pengukuran Sasaran Implementasi elearning dapat dilihat pada Tabel 8 :

Realisasi target nomor 1 diolah dari kuesioner pernyataan nomor 9, 10, dan 13. Respon dari pernyataan-pernyataan ini disajikan ulang dalam table 9 .

\section{TABEL 9. DAFTAR PERNYATAAN YANG BERKAITAN DENGAN MINAT ATAS MATA KULIAH PEMROGRAMAN BASIS DATA}

\begin{tabular}{|c|c|c|c|c|c|c|}
\hline Pernyataan & $\underbrace{2}_{\infty}$ & $\underbrace{e}_{\infty}$ & $\underbrace{e^{\mathfrak{e}}}_{\simeq}$ & $\underbrace{\overbrace{}^{2}}_{\mathscr{\infty}}$ & 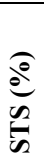 & $\begin{array}{l}e^{0} \\
\text { n } \\
+ \\
\infty\end{array}$ \\
\hline $\begin{array}{l}\text { Belajar menggunakan } \\
\text { materi e-learning ini } \\
\text { mendorong Anda ingin } \\
\text { mempelajari } \\
\text { pemrograman basis } \\
\text { data lebih jauh. }\end{array}$ & 17 & 73 & 10 & 0 & 0 & 90 \\
\hline $\begin{array}{l}\text { Belajar menggunakan } \\
\text { materi e-learning ini } \\
\text { terasa menyenangkan. }\end{array}$ & 23 & 60 & 17 & 0 & 0 & 83 \\
\hline $\begin{array}{l}\text { Adanya materi e- } \\
\text { learning ini } \\
\text { memberikan Anda } \\
\text { kemudahan dalam } \\
\text { mempelajari } \\
\text { pemrograman basis } \\
\text { data. }\end{array}$ & 27 & 60 & 13 & 0 & 0 & 87 \\
\hline
\end{tabular}

\section{KESIMPULAN}

Penelitian ini menghasilkan konten $e$ learning untuk mata kuliah pemrograman basis data yang diintegrasikan pada aplikasi e-learning iDea Universitas Telkom. Konten e-learning mata kuliah pemrograman yang telah dibangun akan diterapkan dalam sistem pembelajaran mata kuliah pemrograman basis data pada mahasiswa program studi D3 Manajemen Informatika.

Berdasarkan hasil pengujian dan pengukuran konten e-learning mata kuliah pemrograman basis data yang dibangun mampu memberikan solusi terhadap permasalahan yang terjadi yaitu dengan adanya konten e-learning mata kuliah pemrograman basis data yang diintegrasikan pada aplikasi e-learning iDea dapat meningkatkan minat belajar mahasiswa sebesar $87 \%$ dan $83 \%$ memahami materi pemrograman basis data. Sedangkan hasil pengujian terhadap ketertarikan konten materi e-learning rata-rata menunjukkan respon positif. Proses evaluasi yang dilakukan baru terhadap materi kajian 1, namun hasil evaluasi nilai tugas dan assessment menunjukkan hasil yang baik dengan prosentase kelulusan assessment 1 sebesar 94,12 \% melebihi dari target kelulusan yang harus dicapai yaitu $90 \%$.

Dengan adanya konten e-learning pada portal iDea mahasiswa dapat belajar secara mandiri dan mudah memahami materi pemrograman basis data tanpa harus mengandalkan penjelasan dosen di kelas.

Dengan demikian penelitian ini berhasil meningkatkan minat dan pemahaman mahasiswa terhadap mata kuliah pemrograman basis data. Hal ini tentunya menjadikan motivasi belajar terhadap mata kuliah pemrograman basis data menjadi meningkat.

Untuk pengembangan selanjutnya sebaiknya dikembangkan model soal assessment interaktif agar lebih bervariasi tidak hanya dalam bentuk pilihan ganda.

\section{DAFTAR PUSTAKA}

Allen, M. (2013). Michael Allen's Guide to Elearning. Canada: John Wiley \& Sons.

Budi, \& Nurjayanti, B. (2012). Pengembangan Metode Pembelajaran Online Berbasis E-Learning. Jurnal Sains Terapan , 2 (1), 103-113.

Budiawan, R., \& Maesaroh, L. (2015). Implementasi Konten E-Learning Mata Kuliah Fisika Studi Kasus : D3 Teknik Komputer, Universitas Telkom. Jurnal Infotel , 7 (2), 1-8.

Chandrawati, S. R. (2010). Pemanfaatan E-learning dalam Pembelajaran. Jurnal Cakrawala Kependidikan , 8 (2), 1-10.

Faesal, A., \& Dasriani, N. G. (2015). Rancang Bangun Media Perangkat Bantu Pembelajaran Berbasis E-Learning Untuk Mata Kuliah Pemrograman. Jurnal MATRIK, 14 (2), 1-7.

Hidayat, A., \& Shinta, Q. (2012). Penerapan eLearning sebagai suatu metode pembelajaran berbasis teknologi informasi (Studi Kasus : Mata Kuliah Pemrograman Berbasis Visual di STMIK PROVINSI). Jurnal Teknologi Informasi dan Komunikasi , 3 (2), 55-61.

Kosasi, S. (2015). Perancangan E-Learning untuk Meningkatkan Motivasi Belajar Guru dan Siswa. Seminar Nasional Pendidikan Teknik Informatika (pp. 1-7). Singaraja-Bali: Universitas Pendidikan Ganesha.

Permana, P. (2013). Efektifitas Penerapan Learning Management System (LMS) Dalam Meningkatkan Kemampuan Menulis Mahasiswa Bahasa Jerman. Allemania , 2 (2), 136-151. 
Pressman, R. S. (2010). Software engineering: a practitioner's approach. New York: McGrawHill Education.
Williams, B. K., \& Stacey C S. (2007). Using Information Technology. Pengenalan Praktis . Yogyakarta: Penerbit Andi. 